\title{
18- Covid-19 salgını sürecinde uygulanan Türkçe öğretmenliği acil uzaktan öğretim programının SWOT analizi ${ }^{1}$
}

\section{Mustafa EMEK²}

APA: Emek, M. (2021). Covid-19 salgını sürecinde uygulanan Türkçe öğretmenliği acil uzaktan öğretim programının SWOT analizi. RumeliDE Dil ve Edebiyat Araştırmaları Dergisi, (Ö10), 308324. DOI: 10.29000/rumelide.1011429.

\section{$\ddot{\mathbf{O} z}$}

$\mathrm{Bu}$ çalışmanın amacı Türkçe öğretmeni adaylarının görüşlerinden hareketle Covid-19 salgını sürecinde uygulanan Türkçe öğretmenliği acil uzaktan öğretim programının SWOT analizini yapmaktır. Çalışma grubunu Kahramanmaraş Sütçü İmam Üniversitesi Eğitim Fakültesi Türkçe Öğretmenliği Programında farklı sınıflarda öğrenim gören 118 Türkçe öğretmeni adayı oluşturmaktadır. Çalışmada nitel araştırma yaklaşımı kullanılmıştır. Araştırma yöntemi olarak olgu bilim (fenomenoloji) esas alınmıştır. Verilerin toplanmasında SWOT analizi yöntemine uygun olarak hazırlanan ve uzman görüşü alınan 4 açık uçlu sorunun yer aldığı yarı yapılandırılmış form kullanılmıştır. Verilerin analizinde ise içerik analizinden yararlanılmıştır. Türkçe öğretmeni adaylarının görüşlerinden hareketle Türkçe öğretmenliği acil uzaktan öğretim programının güçlü yönleri, zayıf yönleri, sunduğu firsatlar ve neden olabileceği tehlikelere ilişkin bulgular elde edilmiştir. Türkçe öğretmeni adaylarının görüşlerinden hareketle acil uzaktan Türkçe öğretim programının ders dokümanlarına sınırsız erişim sağlama, zaman ve öğrenme ortamı bakımından esneklik ve dijital yetkinlik kazandırma gibi güçlü yönlerinin olduğu ulaşılan sonuçlar arasındadır. Ayrıca acil uzaktan öğretim programının iletişim ve etkileşim yetersizliği, teknolojik donanım eksikliği nedeniyle derslerin takip edilememesi ve uygulamalı derslerin yapılamaması gibi zayıf yönlerinin olduğu sonucuna ulaşılmıştır. Programın bilgiye hızlı ve kolay erişim sağlama, araştırma merakını ve teknoloji kullanım yetkinliğini arttırma gibi firsatlar sunduğu tespit edilmiştir. Teknoloji bağımlılığına neden olma, bireysel yalnızlık ve yaşanabilecek sağlık sorunları ise acil uzaktan Türkçe öğretim programının tehlikeleri arasındadır.

Anahtar kelimeler: Acil uzaktan öğretim, Koronavirüs, Türkçe öğretimi, Türkçe öğretmeni adayı, uzaktan eğitim, uzaktan öğretim

\section{SWOT analysis of Turkish teaching emergency remote teaching program implemented during the Covid-19 epidemic}

\author{
Abstract \\ The aim of this study is to make a SWOT analysis of the Turkish teaching emergency remote teaching \\ program applied during the Covid-19 epidemic, based on the opinions of Turkish preservice teacher. \\ The study group consists of 118 Turkish preservice teacher studying in different classes in \\ Kahramanmaraş Sütçü İmam University Faculty of Education Turkish Teaching Program. \\ Qualitative research approach was used in the study. The research method was based on \\ Kahramanmaraş Sütçü İmam Üniversitesi, Sosyal ve Beşeri Bilimler Etik Kurul Kararlarının 2021/34 sayılı yazısı ile \\ araştırma için gerekli olan etik kurur izni alınmıştır. \\ Dr. Öğr. Üyesi, Kahramanmaraş Sütçü İmam Üniversitesi, Eğitim Fakültesi, Türkçe ve Sosyal Bilgiler Eğitimi Bölümü, \\ Türkçe Ĕ̆itimi ABD (Kahramanmaraş, Türkiye), mustafaemek5@gmail.com, ORCID ID: oooo-ooo2-7959-6235 \\ [Araştırma makalesi, Makale kayıt tarihi: 01.10.2021-kabul tarihi: 20.10.2021; DOI: 10.2900o/rumelide.1011429] \\ Adres $\mid$ Address \\ RumeliDE Dil ve Edebiyat Araştırmalar Dergisi $\quad$ RumeliDE Journal of Language and Literature Studies \\ Osmanağa Mahallesi, Mürver Çiçeği Sokak, No:14/8 $\quad$ Osmanağa Mahallesi, Mürver Çiçeği Sokak, No:14/8 \\ Kadıköy - İSTANBUL / TÜRKIYE 34714 Kadıköy - ISTANBUL / TURKEY 34714 \\ e-posta: editor@rumelide.com e-mail: editor@rumelide.com, \\ tel: +90 505 7958124, +90 2167730616 phone: +90 505 7958124, +90 2167730616
}


phenomenology. A semi-structured form including 4 open-ended questions prepared in accordance with the SWOT analysis method and expert opinion was used to collect the data. Content analysis was used in the analysis of the data. Based on the opinions of the Turkish preservice teacher, the findings regarding the strengths, weaknesses, opportunities and threats of the Turkish teaching emergency remote teaching program were obtained. Based on the opinions of Turkish preservice teacher, it is among the results that the emergency remote Turkish teaching program has strengths such as providing unlimited access to course documents, flexibility in terms of time and learning environment, and digital competence. In addition, it has been concluded that the emergency remote teaching program has weaknesses such as lack of communication and interaction, lack of technological equipment, not being able to follow the lessons and not being able to give practical lessons. It has been determined that the program offers opportunities such as providing quick and easy access to information, increasing research curiosity and technology use competence. Cause of technology addiction, individual loneliness and possible health problems are among the threats of the emergency distance Turkish teaching program.

Keywords: Coronavirus, emergency remote teaching, distance education, remote teaching, Turkish preservice teacher, Turkish teaching

\section{Giriş}

Üniversite insanların istekleri doğrultusunda eğitim aldıkları, bireysel tercihleri sonucunda yerleştikleri programlardaki derslere gönüllü katılım sağladıkları bir eğitim kurumudur. Yüksek öğretim kurumlarında öğrencilere ilgi duydukları bir alanda uzmanlaşma veya yapmak istedikleri bir meslekle ilgili yeterli donanıma sahip olma firsatı sunulur. Dolayısıyla amaçlı ve uzmanlık alanıyla sınırlı özel bir eğitimin verildiği yüksek öğretim kurumlarının öğretim programları da bu doğrultuda hazırlanır. Hubball ve Gold (2007'den aktaran Bozok, 2019) yüksek öğretim programlarının öğrenci odakll, öğrencilerin bilgi, beceri ve yeteneklerini geliştirmeye yönelik ayrıca etkileşime olanak sağlayan, tecrübe kazanma imkânı sunan, öğrenme merkezli bir yapıda olmaları gerektiğini belirtirler. Yüksek öğretim programlarının öğretmenlik alanları anlamında ise akademik bilgi ve uygulama becerisini bir arada vermesi beklenmektedir. Bu sayede öğretmen adayları hem görev yapacakları branşlarla ilgili akademik bilgiye ve beceriye sahip olurken hem de bu bilgi ve becerileri nasıl öğretebileceklerini öğrenirler. Öğretmen adaylarına branşlara göre hangi bilgi veya becerinin nasıl öğretilebileceğiyle ilgili önce üniversitelerde daha sonra ise öğretmenlik uygulaması dersi kapsamında staj yaptıkları okullarda uygulama firsatları sunulur. Böylece öğretmenlik mesleği deneyimlenir ve bu konuda uygulamalı bir farkındalık sağlanır. Lortie (1975’ten aktaran Gök-Çolak \& Efeoğlu, 2021) öğretmen adaylarının bu tecrübelerini "gözlem çıraklı̆̆ı" olarak tanımlar. Türkiye'deki üniversitelerin eğitim fakülteleri bünyesinde bulunan Türkçe öğretmenliği lisans programlarının amacı da gerek Millî Eğitim Bakanlığına bağlı devlet okullarında gerekse özel okullarda ilköğretim ikinci kademe düzeyindeki öğrencilere ana dili olarak Türkçe dersi verecek öğretmenler yetiştirmektir. Bu amaçla Türkçe öğretmeni adayları yüksek öğretim kurumunun öğretmen yetiştirme programları için belirlediği standartlar dikkate alınarak 4 yl süre ile alan eğitimi, alan bilgisi, genel kültür ve meslek bilgisi konularında teorik ve uygulamalı dersler alırlar.

Covid-19 salgınının bütün dünya ülkeleri gibi ülkemizde de görülmesiyle birlikte diğer eğitim öğretim uygulamalarında olduğu gibi yüksek öğretimde ve öğretmen yetiştirme programlarında da değişikliğe gidilmiştir. Yüz yüze ve uygulamalı olarak gerçekleştirilen örgün eğitim yerine acil ve hızlı bir biçimde uzaktan öğretime geçilmiştir. Eğitimde sürekliliği sağlamak adına "acil uzaktan öğretim” şeklinde bir

\footnotetext{
Adres | Address

RumeliDE Dil ve Edebiyat Araştırmaları Dergisi $\quad$ RumeliDE Journal of Language and Literature Studies Osmanağa Mahallesi, Mürver Çiçeği Sokkak, No:14/8 $\quad$ Osmanağa Mahallesi, Mürver Çiçeği Sokak, No:14/8 Kadıköy - İSTANBUL / TÜRKIYE 34714 Kadıköy - ISTANBUL / TURKEY 34714 e-posta: editor@rumelide.com e-mail: editor@rumelide.com,

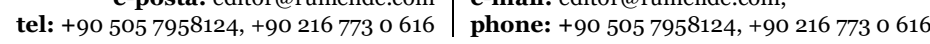


sistem oluşturulmuştur. Salgın öncesinde ülkelere göre uygulama şekli, düzeyi ve kulanım amacı değişiklik gösteren ve örgün eğitime katılamayan kişilere eğitim alma imkânı sunan uzaktan eğitim sisteminin yanı sıra bu dönemde ortaya çıkan acil uzaktan öğretim sistemi hemen her ülkenin kullanması zorunlu hale gelen bir yapıya dönüşmüştür. Gelinen bu noktada uzaktan eğitim tecrübesi olan ve gerekli alt yapıya sahip ülkeler duruma acil uzaktan öğretime uyum sağlamakta avantaj elde ederken diğer ülkelerin bu konuda daha fazla çaba göstermesi ve çalışma yapması gerekmiştir. Böylece dünyada eğitim ve öğretimde yeni bir döneme hızlı, acil ve zorunlu bir geçiş yapılmıştır. Ayrıca bu süreçte uygulamaya konulan acil uzaktan öğretim sisteminin yanı sıra insanların eğitime istedikleri zaman, istedikleri yerden ulaşma isteği, eğitim öğretim teknolojilerinin gelişmesi ve hayat boyu öğrenme anlayışı gibi faktörlerin etkisiyle yaygınlaşan uzaktan eğitim de salgınla birlikte kalıcı hale gelmiştir. Dil öğretiminde ilk kez 1856 yılında Almanya'da kullanılan uzaktan eğitim sistemi daha sonra bütün Avrupa ülkelerinde ve dünyada kullanılmaya başlamıştır (Kırık, 2014). Bir dönem öğretmen yetiştirmede de kullanılan sistem günümüzde özellikle yabancı dil öğretiminde yaygın olarak kullanılmaktadır.

Ülkemizde ise ilk olarak 1960 yllında (Özarslan \& Ozan, 2014) mektupla öğretim sağlama amacıyla kullanılan uzaktan eğitim 1981'de Anadolu Üniversitesi bünyesinde Açık Öğretim Fakültesi açılmasıyla (Gelişli, 2015) ilerleme kaydetmiştir. 1990 yllında Türkiye'deki diğer üniversiteler 1992 yılında ise Millî Eğitim Bakanlığı uzaktan eğitim sistemini kullanmaya başlamıştır (Kaçan \& Gelen, 2020). Günümüzde Millî Eğitim Bakanlığı kısa adı EBA olan Eğitim Bilişim Ağı teknolojisini kullanarak uzaktan eğitim faaliyetlerini gerçekleştirmektedir. Üniversiteler ise UZEM olarak adlandırılan Uzaktan Eğitim Merkezleri aracılı̆̆ıyla eğitim öğretime devam etmektedirler. Bozkurt ve Sharma (2020)'ya göre acil uzaktan öğretim ise uzaktan eğitimden anlam ve kullanım olarak farklı bir kavram ve sistemdir. Uzaktan eğitim yukarıda belirtildiği gibi eski bir tarihi geçmişe sahiptir. Ayrıca etkililiğini kanıtlamak için yıllardır süren çalışmalar yapılmaktadır. Acil ve uzaktan öğretim ise Covid-19 salgını sürecinde ani olarak ortaya çıkan, eğitimde sürekliliği sağlama adına uygulanan geçici bir çözümdür. Salgın sonlandığında bu sisteme ne olacağı henüz belli değildir. Dolayısıyla eski tarihi geçmişe sahip üzerinde yıllardır çalışmalar yapılan bir sistem ile olağanüstü bir durumda ortaya çıkan ve henüz geleceğinin ne olacağı belli olmayan bir diğer sistemin, uygulamanın birbirine karıştıılmaması adına farklı adlandırma yapma yoluna gidilmiştir.

Türkçe öğretmenliği lisans programında acil uzaktan öğretime geçilmesi, derslerin sanal ortama aktarılması ve bilgisayar destekli hale gelmesi olumlu ve olumsuz birtakım değişikliklere neden olmuştur. Bu değişikliklerin neler olduğunun tespiti ve süreçte yaşanan sorunların ortaya çıkarılması için uygulanan öğretim programının değerlendirilmesi gerekmektedir. Türkçe öğretmenliği acil uzaktan öğretim programının değerlendirilmesi birçok açıdan yararlı olacaktır. Öğretim programıyla ilgili ihtiyaçların tespiti, süreçte yaşanan sorunların tespiti, programın verimliliği ve güncellenmesi ya da değiştirilmesi ile ilgili kararlar bu değerlendirme sonucunda ortaya çıkar.

Türkçe öğretmenliği acil uzaktan öğretim programının değerlendirilmesinde birçok yöntem ve yaklaşımdan yararlanılabilir. Söz konusu yaklaşım ve yöntemlerden biri de SWOT analizidir. Bu analiz yöntemi ismini İngilizcedeki "Strengths-Weaknesses-Opportunities-Threats" sözcüklerinin ilk harflerinin birleştirilmesinden almıştır. Türkçede "Güçlü Yönler-Zayıf Yönler-Fırsatlar-Tehditler" sözcüklerinin ilk harflerinin birleştirilmesiyle GZFT analizi şeklinde de kullanılır (Bozok, 2019). Güç çözümlemesi olarak da adlandırılan SWOT analizi 1970'li yıllarda iş yönetimi alanında ortaya çımıştır. İlk olarak Albert S. Humphrey tarafından Stanford Enstitüsünde uygulanmaya başlayan bu analiz yöntemi yönetimde firmaların mevcut durumlarının ve gelecekteki durumlarının tespiti için kullanılmıştır. Ayrıca SWOT analizi kurumların ve firmaların iç ve dış faktörler açısından durumlarını

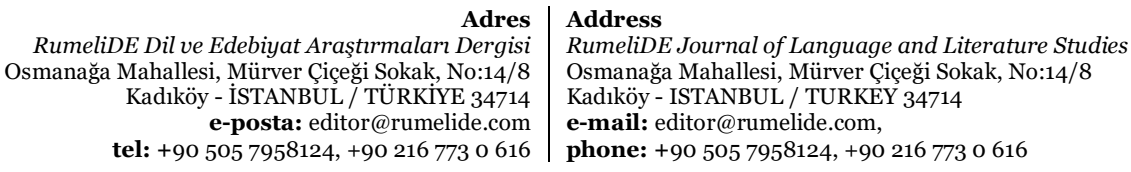


ortaya koyan bir analiz yöntemidir (Birel, 2008). Dört aşamalı olarak gerçekleştirilen bu analizde güçlü yönler (strengths) firmanın ya da kurumun başarılı olduğu, diğer firma ve kurumlardan üstün olduğu tarafları iyi olduğu konuları ifade etmektedir. Zayıf yönler (weaknesses) ise kurumun ya da firmanın rakiplerine göre daha az başarılı olduğu, rakiplerinden geride kaldığı tarafları ifade etmektedir. Firsatlar (opportunities) ile kurumu doğrudan ya da dolaylı olarak olumlu etkileyen dış faktörler kastedilmektedir. Bu anlamda firsatlar kurumun gelişmesini teşvik edici öğelerdir. Tehditler (threats) ise kurumun amaçlarını gerçekleştirmesine engel olan olumsuz yapıdaki dış kaynaklı faktörlerdir (Aköz, 2019). Bu anlamda SWOT analizinde güçlü ve zayıf yönler kurum içi, firsatlar ve tehditler ise kurum dışı faktörler olarak yer almaktadır.

İş yönetiminde ortaya çıan SWOT analizi günümüzde eğitim yönetiminde ve program geliştirmede de kullanılmaktadır. Eğitim alanında SWOT analizi kurumun veya programın iç (güçlü ve zayıf yönler) ve dış (firsatlar ve tehlikeler) etkenlerini ortaya çıkaran bir yöntem olarak kabul edilir (Gökmenoğlu \& Eret, 2011). Eğitim kurumlarının kurum içi ve kurum dışı faktörlerin etkisiyle mevcut durumlarının tespit edilmesi ve gelecekteki durumlarıyla ilgili ön görüler geliştirilebilmesi için düzenli olarak SWOT analizi yapmaları gerekmektedir. Program geliştirme çalışmalarında ise SWOT analizi ihtiyaçların belirlenmesinde kullanılabileceği gibi öğretim programlarının değerlendirilmesinde de bir araç olarak kullanılabilmektedir. SWOT analizi ile uygulanan öğretim programlarının verimliliği ölçülmekte, güçlü ve zayif yönleri tespit edilebilmektedir (Aköz, 2019). Yine SWOT analizi kullanılarak öğrenci ve öğretmenlerin öğretim programıyla ilgili algıları, programın güçlü ve zaylf yanları ile ilgili görüşleri tespit edilerek bu tespitler doğrultusunda öğretim programı şekillendirilebilir (Orr, 2013). Ayrıca öğretimde uygulanması gereken yeni bir yol, yaklaşım, yöntem, teknoloji veya uygulama SWOT kullanılarak analiz edilebilir ve değerlendirilebilir (Penchev, 2021). Yine Orr (2013) öğretmen yetiştirme programının ya da herhangi bir programın SWOT analizinin yapılmasının değişimin uygulanması için itici güç olacağını belirtir.

\section{Araştırmanın önemi}

Teknolojideki gelişmeler ve insanoğlunun öğrenmeye yönelik ihtiyaç, beklenti ve koşullarının her geçen gün biraz daha kişiselleşmesi uzaktan eğitimin yaygınlaşmasını hızlandırmıştır. Her ülkede farklı düzeylerde ve şekillerde kullanılan uzaktan eğitim sistemleri insanlara istedikleri yerde istedikleri zaman öğrenme imkânı sunmaktadır. Uzaktan eğitim firsat eşitliği sunma, eğitimde değişik seçenekler oluşturma, eğitim programlarında standartlaşmayı sağlama, ekonomik olma, bireysel ve bağımsız öğrenmeyi destekleme gibi avantajlara sahip olmakla birlikte yüz yüze iletişim ve etkileşim sağlayamama, sosyalleşmeyi engelleme, uygulamaya yönelik derslerde yetersiz kalma gibi birtakım dezavantajlara da sahiptir (Kaya, 2002). Bu nedenle uzaktan eğitim sistemlerinin eğitimde kullanılmasıyla ilgili birtakım tartışmalar bulunmaktadır. Bazı ülkeler uzaktan eğitime bu tartışmalar nedeniyle mesafeli yaklaşmaktadırlar. Bazı ülkeler ise uzaktan eğitimden etkili bir şekilde yararlanmaktadır. Gerek bu tartışmalara katkı sağlamak gerekse uzaktan eğitimin biraz daha anlaşılır hale gelmesini sağlamak amacıyla konuyla ilgili bilimsel araştırmalar artarak devam etmektedir.

Covid-19 salgınının bütün bu tartışmaların önüne geçerek dünyayı eğitim öğretimde yeni bir sistem olan acil uzaktan öğretime mecbur bırakması uzaktan eğitimle acil uzaktan öğretimi karşılaştıran, uzaktan eğitimin acil uzaktan öğretimde kullanılabilecek yönlerini ele alan ve bu yeni sistemin sorunların en aza indirmeye yönelik akademik çalışmalara olan ihtiyacı ortaya çıardı. Uzaktan eğitime yönelik bilimsel araştırmalar Covid-19 salgını döneminde acil uzaktan öğretimle kesintisiz eğitim için yapılan ve yapılabilecek uygulamalara yönelmiştir. Henüz uzaktan eğitim konusunda yeterli alt yapıya sahip 
olmayan ülkelerde çalışmalar farklı bir rota izlerken alt yapı eksiklerini gidermiş ama uygulama eksiği bulunan ülkelerde ise daha farklı bir rota izlemektedir. Uzaktan eğitim konusunda hem alt yapı hem de uygulama bakımından yeterli düzeyde olan ülkelerde ise çalışmalar daha farklı bir dağılım izlemektedir. Uzaktan eğitim alt yapısı ve tecrübesi ne olursa olsun bütün ülkeler sorunları tespit edip çözümler üretebilmek ve yeni yollar, yaklaşımlar, programlar geliştirebilmek için Covid-19 salgınında yürütülen acil uzaktan öğretim uygulamalarıyla ilgili akademik çalışmalara ihtiyaç duymaktadırlar. Covid-19 döneminde öğretmen yetiştirmede kullanılan acil uzaktan öğretimle ilgili yapılacak çalışmalar da alana katkı sağlayacaktır.

Covid-19 döneminde öğretmen yetiştirme, Covid-19 sürecinde uygulanan öğretmen yetiştirmeye yönelik uzaktan öğretim programları konularında Türkiye'de ve dünyada yapılan çalışmalara bakıldığında konu, örneklem, yöntem bakımından çeşitliliğin olduğu görülmüştür. Ayrıca bazı çalışmalar teorik yapıdayken bazı çalışmaların ise literatür taraması şeklinde ya da uygulamaya dönük olduğu tespit edilmiştir. Carrillo ve Assunção-Flores (2020) çalışmalarında Covid-19 döneminde uzaktan öğretmen yetiştirme konusunda yazılmış, veri tabanları aracılığıyla ulaştıkları 134 araştırma makalesini konuları, makalelerde yer verilen uzaktan öğretmen yetiştirmeye yönelik uygulamalar ve sonraki araştırmaların nasıl bir şekilde devam ettirilmesi gerektiği yönlerinden incelemişlerdir. König, Jäger-Biela ve Glutsch (2020) çalışmalarında göreve yeni başlayan öğretmenlere Covid-19 sürecinde nasıl bir öğretim gerçekleştirdikleriyle ilgili anket uygulayarak Almanya'daki öğretmen eğitimini ele almışlardır. Van Nuland, Mandzuk, Tucker-Petrick ve Cooper (2020) Covid-19'un Ontario'daki öğretmen eğitimine etkilerine yönelik bir çalışma gerçekleştirmişlerdir. Bu dönemde Ontario'da nelerin değiştiğini ne gibi yeniliklerin yapıldığını yüz yüze gerçekleştirilen öğretmen eğitimi programıyla karşılaştırmalı olarak ele almışlardır. Ellis, Steadman ve Mao (2020) ise Covid-19 sürecinin dünyada öğretmenlik eğitiminde bir yeniliğe (inovasyona) neden olup olamayacağını araştırmışlardır. Assunção-Flores ve Gago (2020) çalışmalarında Covid-19 sürecinde Portekiz'deki öğretmen eğitimini ulusal, kurumsal ve pedagojik açllardan değerlendirirler. Süreci neden olduğu zorluklar ve sağladığı firsatlar bakımından Portekiz özelinde ele alırlar. Hadar, Ergas, Alpert ve Ariav (2020) Covid-19 sürecinde öğretmen adaylarının sosyal duyusal yeterliliklerini inceledikleri çalışmalarında İsrail'deki 54 öğretmen adayı ve 24 öğretmenle konuyla ilgili görüşme gerçekleştirmişlerdir. Kidd ve Murray (2020) Covid-19 sürecinin İngiltere'deki öğretmen eğitimini nasıl etkilediğini araştırmışlardır. Sürecin öğretmen eğitiminde neden olduğu değişiklikler ayrıntılı ve anlamlı bir şekilde tanımlanmaya çalışılmıştır. La Velle, Newman, Montgomery, Hyatt (2020) ise İngiltere'de Covid-19 döneminde uygulanan öğretmen yetiştirme programını firsatlar ve zorluklar bakımından değerlendirmişlerdir.

Covid-19 sürecinde yüksek öğretim, öğretmen eğitimi, Türkçe öğretmeni yetiştirme konularında Türkiye'de yapılan çalışmalar incelendiğinde Saltürk ve Güngör (2020)'ün Covid-19 sürecinde uzaktan eğitime geçiş deneyimini öğrenci bakış açısıyla ele aldıkları görülmüştür. Yine Er-Türküresin (2020) Covid-19 salgınında gerçekleşen uzaktan eğitime geçiş sürecini öğretmen adaylarının görüşlerinden hareketle ortaya koymuştur. Duban ve Şen (2020) çalışmalarında sınıf öğretmeni adaylarının Covid-19 sürecine ilişkin görüşlerini ele almışlardır. Telli-Yamamoto ve Altun (2020) Coronavirüs döneminde uzaktan eğitim çalışmalarının değerlendirmesini yapmışlardır. Karakuş, Ucuzsatar, Karacaoğlu, Esendemir, Bayraktar (2020) İstanbul'daki bir üniversitede öğrenim gören Türkçe öğretmeni adaylarının uzaktan eğitime yönelik görüşlerini ele almışlardır. Gökbulut (2021) ise çalışmasında 358 üniversite öğrencisinin görüşlerinden hareketle uzaktan eğitim sürecini değerlendirmiştir. Gök-Çolak ve Efeoğlu (2021) İstanbul'da yer alan bir üniversitede öğrenim gören 10 okul öncesi öğretmeni adayı ve 10 İngilizce öğretmeni adayının görüşlerinden hareketle yeni normalleşme dönemi olarak adlandırdıkları Covid-19 sürecinde eğitim fakültelerinde verilen öğretmenlik uygulaması dersine

Adres | Address

RumeliDE Dil ve Edebiyat Araşturmalar Dergisi $\quad$ RumeliDE Journal of Language and Literature Studies Osmanağa Mahallesi, Mürver Çiçeği Sokak, No:14/8 $\quad$ Osmanağa Mahallesi, Mürver Çiçeği Sokak, No:14/8 Kadıköy - ISTANBUL / TURKIYE 34714 Kadıköy - ISTANBUL / TURKEY 34714 e-posta: editor@rumelide.com e-mail: editor@rumelide.com, tel: +90 505 7958124, +90 2167730616 phone: +90 505 7958124, +90 2167730616 
yönelik SWOT analizi yöntemini kullanarak bir ihtiyaç analizi gerçekleştirmişlerdir. Özüdoğru (2021) çalışmasında öğretmen adaylarının deneyimlerinden hareketle acil uzaktan öğretim sürecini değerlendirmiştir. Araştırmaya Uşak Üniversitesinde öğrenim gören farklı branşlardan 24 öğretmen adayı katılmıştır. Ustabulut (2021) yabancı dil olarak Türkçe öğreten öğretmenlerin görüşlerinden hareketle Covid-19 salgını sürecinde uzaktan Türkçenin yabancı dil olarak öğretimiyle ilgili durumu ortaya koymuştur. Uysal-Bayrak ve Tanık-Önal (2021) 52 okul öncesi öğretmeni adayının görüşlerinden hareketle uzaktan eğitimin SWOT analizini yapmışlardır.

Alan yazın tarandığında Türkçe öğretmeni adaylarının görüşlerinden hareketle Covid-19 sürecinde uygulanan lisans düzeyi Türkçe öğretmenliği acil uzaktan öğretim programının SWOT analizini yapan bir çalışmaya rastlanılmamıştır. Bu çalışmanın öğretmen adaylarının görüşlerinden hareketle Türkçe öğretmenliği acil uzaktan öğretim programının güçlü ve zayıf yanları, sunduğu firsatlar ve neden olabileceği tehditler konularında alana katkı sağlayacağı düşünülmektedir.

\section{Araştırmanın amacı}

$\mathrm{Bu}$ araştırmanın amacı öğrenci görüşlerinden hareketle Covid-19 salgını sürecinde uygulanan Kahramanmaraş Sütçü İmam Üniversitesi Türkçe Öğretmenliği acil uzaktan öğretim programının SWOT analizini yapmaktır. Çalışmanın araştırma soruları şu şekildedir:

1. Covid-19 salgını sürecinde uygulanan lisans düzeyi Türkçe öğretmenliği acil uzaktan öğretim programının güçlü yönleri nelerdir?

2. Covid-19 salgını sürecinde uygulanan lisans düzeyi Türkçe öğretmenliği acil uzaktan öğretim programının zayıf yönleri nelerdir?

3. Covid-19 salgını sürecinde uygulanan lisans düzeyi Türkçe öğretmenliği acil uzaktan öğretim programının sunduğu firsatlar nelerdir?

4. Covid-19 salgını sürecinde uygulanan lisans düzeyi Türkçe öğretmenliği acil uzaktan öğretim programının neden olduğu tehlikeler nelerdir?

\section{Araştırmanın sınırlılıkları}

Araştırma Kahramanmaraş Sütçü İmam Üniversitesi Türkçe Öğretmenliği Programı öğrencilerinden çalışmayla ilgili veri toplama formunu dolduran 118 Türkçe öğretmeni adayının görüşleri ile sınırlıdır. Çalışmada acil uzaktan öğretim lisans programıyla ilgili bölümdeki ulaşılabilen 118 Türkçe öğretmeni adayının görüşleri Google Form aracılığıyla alınmıştır, bölümdeki diğer öğretmen adayları, öğretim üyeleri, yöneticiler ve öğrenci velilerinin görüşleri dikkate alınmamıştır. Türkçe öğretmeni adaylarının görüşlerinden elde edilen veriler içerik analizi tekniği kullanılarak işlenmiştir. Verilerin toplanması ve analizinde belirtilenlerin dışında betimsel, istatistiksel, ilişkisel vb. herhangi bir çözümleme işlemi gerçekleştirilmemiştir.

\section{Yöntem}

Çalışma nitel araştırma türünde tasarlanmıştır. Araştırmanın amacı Türkçe öğretmeni adaylarının acil uzaktan öğretim programıyla ilgili düşüncelerini ortaya koymak olduğu için yöntem olarak olgu bilim (fenomenoloji) kullanılmıştır. Ayrıca Türkçe öğretmeni adaylarının konuyla ilgili düşüncelerinin ne olduğuyla ilgili ayrıntılı bilgiye sahip olma, konuyu tam olarak anlama isteği (Yıldırım \& Şimşek, 2011) olgu bilim yönteminin tercih edilmesinin bir diğer gerekçesini oluşturmaktadır. Bu şekilde Türkçe öğretmeni adaylarının deneyimlerinin arkasındaki gerçeğin elde edilmesi (Merriam, 2015)

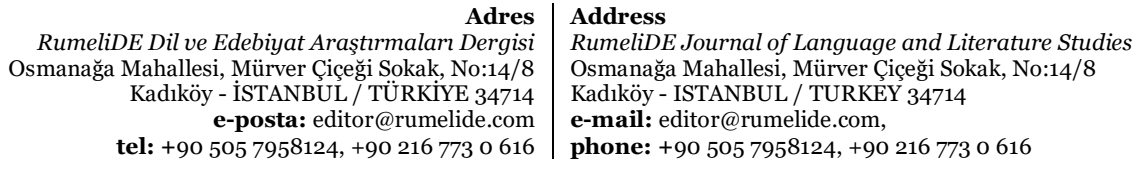


amaçlanmaktadır. Çalışmanın fenomenini uzaktan Türkçe öğretim programı oluşturmaktadır. Araştırma Türkçe öğretmeni adaylarının Covid-19 sürecinde uygulanan uzaktan Türkçe öğretim programıla ilgili deneyimlerinden kaynaklı düşüncelerini içermektedir. Çalışmada Türkçe öğretmeni adayları uzaktan öğretim programıla ilgili deneyimlerini kendilerine sorulan sorulardan hareketle betimlemişlerdir ve araştırmacı bu olgunun ortak anlamını tanımlamıştır (Creswell, 2017). Bu süreçte odak noktası olarak Türkçe öğretmeni adaylarının öznel deneyimleri alınmıştır ve araştırmacı tarafından katılımcılara hiçbir düşünce empoze edilmeden uzaktan Türkçe öğretim programı onların yaşadığı tecrübelerle anlaşılmaya çalışılmıştır (Çekmez, Yıldız \& Bütüner, 2012).

\section{Çalışma grubu}

Araştırmanın çalışma grubunu Kahramanmaraş Sütçü İmam Üniversitesi Eğitim Fakültesi Türkçe Öğretmenliği Programında bulunan farklı sınıf düzeyinde öğrenim gören 118 Türkçe öğretmeni adayı oluşturmaktadır. Programda okuyan toplam aktif Türkçe öğretmeni adayı sayısı 204'tür. Araştırma grubunu oluşturan Türkçe öğretmeni adaylarıyla ilgili veriler aşağıda verilmiştir.

Tablo 1. Türkçe öğretmeni adaylarının cinsiyet teknoloji kullanma ve teknoloji ürünlerine sahip olma dağılımı

\begin{tabular}{|c|c|c|c|}
\hline \multirow[t]{3}{*}{ Türkçe öğretmeni adaylarının cinsiyete göre dağılımı } & Cinsiyet & $f$ & $\%$ \\
\hline & Kadın & 85 & 72,03 \\
\hline & Erkek & 33 & 27,96 \\
\hline \multirow{4}{*}{$\begin{array}{l}\text { Türkçe öğretmeni adaylarının bilgisayar internet ve } \\
\text { teknoloji ürünlerini kullanma düzeyi }\end{array}$} & Düzey & $f$ & $\%$ \\
\hline & İyi & 35 & 29,66 \\
\hline & Orta & 66 & 55,93 \\
\hline & Geliştirilebilir & 17 & 14,40 \\
\hline \multirow{5}{*}{$\begin{array}{l}\text { Türkçe öğretmeni adaylarının bilgisayar veya akıllı } \\
\text { telefona ve düzenli internete sahip olma durumu }\end{array}$} & Durum & $\mathrm{f}$ & $\%$ \\
\hline & Evet sahibim & 88 & 74,57 \\
\hline & Hayır sahip değilim & 21 & 17,79 \\
\hline & $\begin{array}{l}\text { Akıllı telefonum var bilgisayarım ve } \\
\text { düzenli internetim yok }\end{array}$ & 7 & 5,93 \\
\hline & Genellikle sahibim & 2 & 1,69 \\
\hline
\end{tabular}

\section{Veri toplama araçları}

Veri toplama aracı olarak SWOT analizi yaklaşımı esas alınarak ve uzman görüşüne başvurularak oluşturulan yarı yapılandırılmış form kullanılmıştır. Form "Google Form" uygulaması kullanılarak oluşturulmuş ve uygulanmıştır. Formda iki bölüm bulunmaktadır. Birinci bölümde Türkçe öğretmeni adaylarının teknoloji kullanma yeterlilikleri ve teknolojik imkanlara sahip olma düzeylerinin tespiti amaçlanmıştır. İkinci bölüm ise uzaktan eğitim şeklinde uygulanan Türkçe öğretmenliği acil uzaktan öğretim lisans programının güçlü ve zayıf yanları, avantajları ve neden olabileceği tehlikeleri tespit etmeye yönelik dört adet açlk uçlu sorudan oluşmaktadır. Türkçe öğretmeni adaylarının objektif değerlendirme yapabilmeleri için formda onlara cinsiyetleri dışında kişisel bilgi sorulmamıştır. Türkçe öğretmeni adaylarından okudukları sınıf, e-posta adresleri, yaşları, telefon numaraları vb. veriler istenmemiştir.

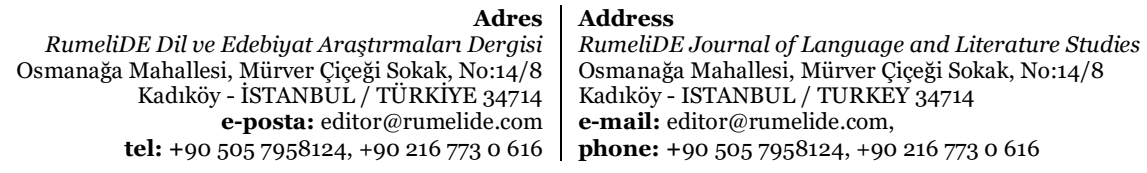

Adres
RumeliDE Dil ve Edebiyat Araştırmaları Dergisi Kadiköy - İTTANBUL / TÜRKIYE 34714 tel: +90 505 7958124, +902167730616 


\section{Veri toplama süreci}

Veri toplama sürecinde ilk olarak çalışmayla ilgili evraklar hazırlanarak etik kurul iznine başvurulmuştur. Kahramanmaraş Sütçü İmam Üniversitesi Sosyal ve Beşerî Bilimler Etik Kurulu'nun 07.07.2021 tarihli 2021/34 toplantı sayılı kararında araştırmanın gerçekleştirilmesinin uygun olduğu ifade edilmiştir. Daha önce hazırlanmış olan ve etik kurul onayından geçen formun giriş kısmında Türkçe öğretmeni adaylarına gerekli bilgiler verilmiştir. Bu bölümde Türkçe öğretmeni adaylarına araştırmanın amacı, önemi, formun nasıl doldurulması gerektiği ve onlardan elde edilen verilerin güvenli bir şekilde nasıl kullanılacağı gibi konularda ön bilgiler sunulmuştur. Daha sonra sınıf WhatsApp grupları aracılığıyla tekrar yazılı açıklamalar yapılmış, Türkçe öğretmeni adaylarından gelen konuyla ilgili sorular cevaplanmıştır. Son aşamada ise öğretmen adaylarıyla formun bağlantı adresi paylaşılmıştır. Onlara formu doldurup geri göndermeleri için iki hafta süre tanınmıştır. Bu süre içerisinde sık sık sınıf WhatsApp gruplarından katılımın gönüllü olduğu, yanıtlarının sadece bilimsel amaçlarla kullanılacağı, kişisel bilgiler belirtilmeden işleneceği belirtilerek Türkçe öğretmeni adayları formu doldurmaya davet edilmiştir. Onlardan Google Form aracılığıyla yöneltilen dört açık uçlu soru ile salgın döneminde uygulanan Türkçe öğretmenliği acil uzaktan öğretim lisans programını değerlendirmeleri istenilmiştir. İki haftalık veri toplama sürecinin ardından elde edilen veriler analiz edilerek ulaşılan sonuçlar bulgular kısmında ifade edilmiştir.

\section{Verilerin analizi}

Çalışma verilerinin çözümlenmesinde içerik analizi yaklaşımı kullanılmıştır. Türkçe öğretmeni adayları tarafından uzaktan öğretim programının analizine ilişkin sorulara verilen cevaplar araştırmacı tarafından oluşturulan ortak başlıklar altında toplanmış ve yorumlanmıştır (Yıldırım \& Şimşek, 2011).

\section{Bulgular}

\section{Birinci araştırma sorusuna yönelik bulgular}

Türkçe öğretmeni adaylarının acil uzaktan öğretim programının güçlü yönlerinin neler olduğuyla ilgili soruya verdikleri cevaplara ilişkin bilgiler Tablo 2'de gösterilmiştir.

Tablo 2. Türkçe öğretmenliği acil uzaktan öğretim programının güçlü yönlerine ilişkin bulgular

Sizce Covid-19 salgını sürecinde uygulanan lisans düzeyi Türkçe öğretmenliği acil uzaktan öğretim programının güçlü yönleri nelerdir?

Dersleri istenilen zamanda istenildiği kadar tekrar izleme, ders notlarına ve videolarına ulaşma imkânı 43 sunması

\begin{tabular}{|c|c|c|}
\hline \multicolumn{2}{|l|}{ Teknolojiyi kullanma becerisini geliştirmesi } & 34 \\
\hline \multicolumn{2}{|c|}{ İstenilen zamanda istenilen yerden canlı derse katılma imkânı sunması } & 29 \\
\hline \multicolumn{2}{|c|}{ Ö ̆̆renci ve öğretmen arasında anlık iletişim ve etkileşim sağlaması } & 11 \\
\hline \multicolumn{2}{|c|}{ Ders dışındaki diğer yaşam aktivitelerini gerçekleştirme zamanı sunması } & 9 \\
\hline \multicolumn{2}{|c|}{ Web 2.o uygulamalarını tanıma ve kullanma becerisi sağlaması } & 9 \\
\hline \multicolumn{2}{|c|}{ Fiziksel ve psikolojik olarak ev ortamında ders dinleme rahatlı̆̆ı sunması } & 8 \\
\hline \multicolumn{2}{|l|}{ Ekonomik ve az maliyetli olması } & 6 \\
\hline \multicolumn{2}{|l|}{ Kendi kendine öğrenmeye yönlendirmesi } & 6 \\
\hline \multicolumn{2}{|l|}{ Dersleri geleneksel yaklaşımlardan ve sıkıcılıktan kurtarması } & 5 \\
\hline $\begin{array}{r}\text { Adres } \\
\text { RumeliDE Dil ve Edebiyat Arassttrmaları Dergisi } \\
\text { Osmanağa Mahallesi, Mürver Çiçeği Sokak, No:14/8 } \\
\text { Kadıköy - İSTANBUL / TÜRKIYYE } 34714 \\
\text { e-posta: editor@rumelide.com } \\
\text { tel: +90 505 7958124, +90 216 } 773 \text { o } 616\end{array}$ & $\begin{array}{l}\text { Address } \\
\text { RumeliDE Journal of Language and Literature Studies } \\
\text { Osmanağa Mahallesi, Mürver Cicceği Sokak, No:14/8 } \\
\text { Kadıköy - ISTANBUL / TURKEY } 34714 \\
\text { e-mail: editor@rumelide.com, } \\
\text { phone: +90 505 7958124, +90 } 216773 \text { o } 616\end{array}$ & \\
\hline
\end{tabular}




\begin{tabular}{lc}
\hline Yeni, farklı ve ilgi çekici bir ortam sunması & 4 \\
\hline Dijital okuryazarlık becerisini geliştirmesi & 4 \\
\hline Ders videolarını istenilen yerde durdurup detaylı not alma imkânı sunması & 3 \\
\hline Okuma alışkanlığı geliştirmesi & 2 \\
\hline Bilgiye kolay erişim imkânı sağlaması & 2 \\
\hline Derse canlı katılımın zorunlu olmaması gönüllülük esasına dayalı olması & 2 \\
\hline Sayıca daha fazla ders alma fırsatı sunması & 2 \\
\hline Dinleme izleme becerisini geliştirmesi & 2 \\
\hline
\end{tabular}

Tablo 2 incelendiğinde Türkçe öğretmeni adaylarının acil uzaktan öğretim programının güçlü yanı olarak en çok derslere ve ders notlarına istenildiği yerden, istenildiği zaman ulaşılabilme seçeneğini belirttikleri görülmektedir. Yine acil uzaktan öğretim programının teknolojiyi kullanma becerisini geliştirmesi ve istenilen yerden canlı derslere katılım imkânı sunması Türkçe öğretmeni adaylarının acil uzaktan öğretim programıyla ilgili en çok dile getirdikleri diğer güçlü yanlardır. Acil uzaktan öğretim programının dinleme, izleme becerisini geliştirmesi, fazla sayıda ders alma imkânı sunması ve derse devam zorunluluğunun olmaması ise Türkçe öğretmeni adayları tarafından en az dile getirilen güçlü yanlardandır.

Konuyla ilgili örnek olması bağlamında bazı Türkçe öğretmeni adaylarının (TÖA) veri toplama formlarından hareketle yukarıdaki tabloyu destekler nitelikteki yazılı görüşleri şu şekildedir:

"Derslerin kaydedilmesi, konu anlaşılmasın tam sağlamak amacıyla tekrardan izlenebilmesi, dersi kaçırmış olsa dahi kaydedilen videodan dersin telafisini kolaylıkla sağlanması not tutarken ders kaydının durdurulup detaylı olarak ders notunun tutulması vb. örnekler verilebilir.” (TÖA5)

"Olumlu yanları bence dersi tekrar edebilmemizdi istediğimiz zaman istediğimiz ortamda, saate derse girebiliyor olmak dersi daha verimli hale getirdiğini düşünüyorum bunun dişında dersi istediğimiz kadar izleyebilmek de büyük bir artı bence izledikçe daha fazla bilgi, fikir, düşünceye sahip oluyorsun yanlş̧ların fark edebiliyorsun bunun dışında var olan durum nedeniyle teknolojiyle iç içe olmakta bizleri bu konuda geliştirdiğini söyleyebilirim.” (TÖA29)

"Türkçe öğretmenliği uzaktan eğitim sürecini öğrenciler açısından olumlu buluyorum. Olumlu bulmamda birden çok neden var. Bu nedenlere değinecek olursam; maddi olarak öğrenciyi ve aileleri yıpratmıyor, üniversite eğitimini başka bir şehirden alacak öğrenciyi düşünürsek barımma, yiyecek, ulaşım gibi birçok faktörün varlı̆̆ öğrenciyi maddi anlamda bir külfete sürükleyecektir. Ancak eğitimin uzaktan olmasıyla öğrenci kendi evinin şartlarında bu faktörlere para harcamadan sadece internet masrafiyla eğitimi alacaktır. Manevi açıdan ailesine yük olmayacak, aileden ayrı kalmadan eğitimini alacaktır. Uzaktan eğitim zaman açısından da öğrencilere tasarruf getirmektedir. Ders saatinde dersini dinleyip dersten sonra başka işlerle vaktini geçirebilmektedir. Okuldayken ders aralarında geçen boş zamanlar, evde başka konularla araştırmalarla doldurulabilir. Çeşitli nedenlerle dersten geri kalma durumlarına karşı uzaktan eğitim süreci öğrenciye öneriler ve firsatlar sunmaktadır. Öğrenci dileği zamanda dersini dinleyip istediği şekilde notunu alabilmekte bilmediği konular hakkında internet aracılığıyla çeşitli konuları araştırabilmektedir. Öğretim üyesi açısından olumlu yanları öğrenciye iletmek istediği konuları sunular yoluyla verebilmekte, kendi çalışma alanlarma zamandan tasarruf ederek daha çok katkı sağlayabilmektedir. Okunması araştırılması gereken konular öğrenciye gönderilerek daha verimli bir ders anlatılabilmektedir. Türkçe öğretim

Adres $\mid$ Address

RumeliDE Dil ve Edebiyat Araşturmalar Dergisi $\quad$ RumeliDE Journal of Language and Literature Studies Osmanağa Mahallesi, Mürver Çiçeği Sokak, No:14/8 Osmanağa Mahallesi, Mürver Çiçeği Sokak, No:14/8 Kadıköy - İSTANBUL / TÜRKIYE 34714 Kadıköy - ISTANBUL / TURKEY 34714 e-posta: editor@rumelide.com e-mail: editor@rumelide.com, tel: +90 505 7958124, +90 2167730616 phone: +90 505 7958124, +90 2167730616 
programina olumlu katkılarn ise öğrenci birçok konuda araştırma yapma imkanına sahip olabilmekte çeşitli yönleriyle konular irdeleyecek birçok makaleye ulaşabilmektedir. Türkçe eğitimi fazla uygulama gerektirmeyen bir bölüm olduğu için sözel iletişimle birçok konu irdelenebilmekte ve faydah bilgiler edinilebilmektedir." (TÖA64)

\section{İkinci araştırma sorusuna yönelik bulgular}

Türkçe öğretmeni adaylarının uzaktan öğretim programının zayıf yönlerinin neler olduğuna ilişkin soruya verdikleri yanıtlar Tablo 3'de sıralanmıştır.

Tablo 3. Türkçe öğretmenliği acil uzaktan öğretim programının zayıf yönlerine ilişkin bulgular

Sizce Covid-19 salgını sürecinde uygulanan lisans düzeyi Türkçe öğretmenliği acil uzaktan öğretim programının zayıf yönleri nelerdir?

Devam zorunluluğu olmadığından canlı derslere katılımın ve bu derslerde öğrenci-öğrenci, öğrenciöğretmen iletişiminin yetersiz olması

\begin{tabular}{ll}
\hline Yüz yüze iletişim eksikliği & 28 \\
\hline Derslerin teorik ağırlıklı işlenmesi uygulama ve etkinliklerin olması gerektiği gibi yapılamaması & 27 \\
\hline İnternet bağlantı sorunları nedeniyle ders veriminin düşmesi & 19 \\
\hline Ev ortamının motivasyon disiplin ve öğrenmeyi olumsuz etkilemesi & 14 \\
\hline Yüz yüze ve uygulamalı anlatılması gereken konuların uzaktan eğitimle verilememesi & 11 \\
\hline Gerekli teknolojik donanıma sahip olamayanların dersleri takip etmede zorlanması & 11 \\
\hline Kullanılan uzaktan eğitim alt yapısının sorunlu olması nedeniyle dersleri takip edememe & 10 \\
\hline Öğrencilerin bireysel plan yapma ve hareket etme zorunda kalması & 10 \\
\hline Ölçme değerlendirme sürecinin açık net ve planlı ilerlememesi & 10 \\
\hline $\begin{array}{l}\text { Okul deneyimi ve öğretmenlik uygulaması derslerinin fiziki okul ve sınıf ortamında yapılamasından } \\
\text { kaynaklı mesleki özgüven eksikliği ve deneyimsizlik }\end{array}$ & 9 \\
\hline Kişisel ve kurumsal planlamadaki eksikler nedeniyle duyulan kaygı & 8 \\
\hline Uzaktan eğitimi uygun materyal ve yöntemlerin kullanılamaması nedeniyle derslerin anlaşılamaması & 8 \\
\hline Özellikle birinci sınıflar için okula, kuruma aidiyet hissinin gelişmemesi & 7 \\
\hline $\begin{array}{l}\text { Bazı öğretim üyelerinin teknoloji kullanımı konusundaki eksikleri nedeniyle derslerin verimsiz geçmesi ve } \\
\text { derslerde zaman kaybı yaşanması }\end{array}$ & 4 \\
\hline Çok fazla ödev verilmesi & $\mathbf{4}$ \\
\hline Ders saatlerinin dağılımının yanlış olması & 4 \\
\hline Teknoloji bağımlılığını tetiklemesi & 1 \\
\hline
\end{tabular}

Tablo 3 incelendiğinde devam zorunluluğu olmadığı için canlı derslere katılım oranının düşük olması, öğrenci-öğrenci ve öğretmen-öğrenci arasında iletişimin sınırlı olması, uygulamalı derslerin gerektiği gibi yapılamaması Covid-19 salgını sürecinde uygulanan Türkçe öğretmenliği lisans düzeyi acil uzaktan öğretim programına ilişkin en sık dile getirilen zayıf yönler olarak görülmektedir. Ayrıca acil uzaktan öğretim programının teknoloji bağımlılığını tetiklemesi ve ders saatlerinin dağılımının yanlış olduğunun düşünülmesi Türkçe öğretmeni adayları tarafından dile getirilen en az sıklıktaki zayıf yönler olarak belirtilebilir. Türkçe öğretmeni adaylarının acil uzaktan öğretim programının zayıf yönlerinden biri olarak okul deneyimi ve öğretmenlik uygulaması derslerinin uygulamalı şekilde işlenememesi şeklinde bir tespitte bulunmaları dikkat çekicidir.

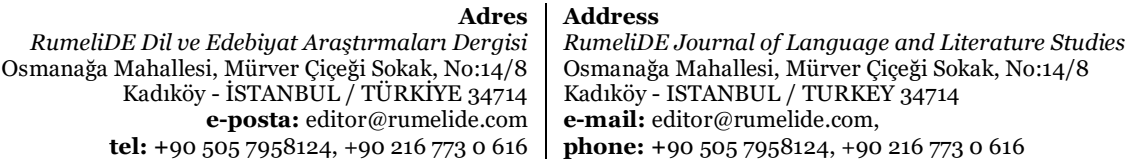

RumeliDE Journal of Language and Literature Studies

Osmanağa Mahallesi, Mürver Çiçeği Sokak, No:14/8

Kadıköy - ISTANBUL / TURKEY 34714

e-mail: editor@rumelide.com

phone: +90 $5057958124,+902167730616$ 
Türkçe öğretmeni adaylarının acil uzaktan öğretim programının zayıf yönlerine ilişkin yazılı görüşlerinden bazılarına aşă̆ıda yer verilmiştir.

"Yüz yüze eğitimin verdiği rahatlk düşünüldüğünde tabii ki de aynı rahatllkta olmadığımı, internete erişim problemlerinden dolayı her öğrencinin etkin olarak derse katılamadiğı ve verim alma noktasında eşitsizliklerin olduğunu söyleyebilirim. Ki özellikle son sını öğrencileri için sahada eğitim görememenin eksikliği ile daha özgüvensiz, deneyimsiz Türkçe öğretmenleri adaylarmm yetiştiğini dile getirebilirim... İletişim sorunları, her öğrencinin aktif olmayışı vb. sorunlar sayılabilir.” (TÖA10)

"Zayıf yönleri bireyin kendi düzeninini disiplinini oluşturması gerekiyor ve ne kadar bizler birer birey olarak en iyi programı da hazırlasak bazı sorunlarla karşılaşıyoruz ev ortamında derslere girdiğimiz için diğer kardeşlerimizin de derse girmesi gerekiyor evle ilgili bir işler oluyor vs gibi disiplin konusunda sıkıntılar oluşuyor kendi elimizde olmadan bunları yaşıyoruz ve Uzaktan eğitim verimli olmayabiliyor." (TÖA29)

"Dil öğretimi ve uygulamalı derslerin ağırlıkta olduğu bir program olma açısından, uzaktan eğitim, yüz yüze eğitimdeki gibi verimli olmamıştır. Öğretmenlik uygulama derslerinin uzaktan yapılması, öğrenci ile iletişimin az olması ve birçok öğrencinin internet kaynakh sorunlar yaşaması uygulama derslerini sekteye uğramıştır. Uzaktan eğitimde yaşanan en büyük sorunlardan biri internet sıkıntısı ve sanal derslere ilginin az olmasıdır." (TÖA66)

\section{Üçüncü araştırma sorusuna yönelik bulgular}

Türkçe öğretmeni adaylarının acil uzaktan öğretim programının sunduğu firsatlara yönelik verdikleri cevaplardan hareketle ulaşlan bulgular Tablo 4’te sıralanmıştır.

Tablo 4. Türkçe öğretmenliği acil uzaktan öğretim programının sunduğu firsatlara yönelik bulgular

\begin{tabular}{ll}
\hline $\begin{array}{l}\text { Sizce Covid-19 salgını sürecinde uygulanan lisans düzeyi Türkçe öğretmenliği acil uzaktan öğretim } \\
\text { programının sunduğu fırsatlar nelerdir? }\end{array}$ & $\mathrm{f}$ \\
\hline Ders videolarına ve dokümanlarına sınırsız erişım & 29 \\
\hline Dijital ilgiyi arttırması, teknoloji kullanma yetkinliği kazandırması & 26 \\
\hline Esnek zaman anlayışı & 22 \\
\hline Diğer yaşam aktivitelerine izin vermesi & 17 \\
\hline Esnek mekân, öğrenme ortamı anlayışı & 16 \\
\hline Bilgiye kolay ve hızlı erişim & 15 \\
\hline Araştırma merakı aşılaması alternatif doküman ve materyal imkânı sunması & 11 \\
\hline Ekonomiklik & 10 \\
\hline Bireysel öğrenmeyi ve kişisel gelişimi destekleme & 10 \\
\hline Dijital sosyalleşme, sosyal gruplar oluşturma firsatı sunma & 7 \\
\hline Eğitimde sürekliliği sağlama & 6 \\
\hline Birçok dersi aynı dönemde alma imkânı sunması & 5 \\
\hline Devam zorunluluğu olmadığından yalnızca istekli öğrencilerin derse katılması & 1 \\
\hline
\end{tabular}

Acil uzaktan öğretim programının ders videoları ve notlarına sınırsız erişim imkânı sunması, dijital ilgi ve yetkinliği arttırması ve esnek zaman anlayışı Türkçe öğretmeni adayları tarafından sıklıkla dile

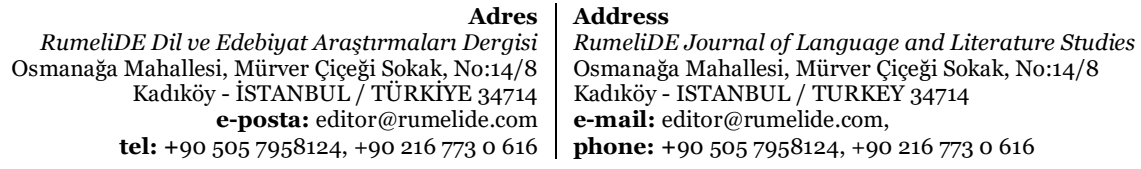


getirilen fırsatlar arasındadır. Acil uzaktan öğretim programında derse katılımın isteğe bağlı olması, birçok ders alma imkânı sunulması ve eğitimde sürekliliğin sağlanması da Türkçe öğretmeni adayları tarafından dile getirilen sıklı̆̆ı diğer maddelere göre az olan firsatlar arasındadır.

Türkçe öğretmenliği acil uzaktan öğretim programının sunduğu fırsatlara ilişkin bazı Türkçe öğretmeni adaylarının yazılı görüşleri aşağıda verilmiştir.

"En önemli firsatı zaman tasarrufu sağladı. Ev geçindirmek zorunda ya da KPSS çalışanlar için vazgeçilmez bir firsattı. Devam zorunluluğu olmaması da bunlara bağh müthiş bir yarar sağladı. Ayrıca ister aynı şehirde olsun isterse farklı bir şehirde olsun öğrenciler için maddi olarak da büyük tasarruf imkânı sundu." (TÖA4)

"Bu süreç bize teknolojizi kullanma başarısı kazandırdı. Sene başında Zoom programını ilk kez duyan ben Zoom'da toplantzlara katıldım, toplantılar başlattım, ders dinledim ve ders anlattım, ekran paylaştım ve farkh sitelerden derlediğim konuyla ilgili güzel etkinlik ve sinavları sinıfa sundum böylece dersteki materyal kullanımı becerimi de artırdım." (TÖA15)

"Firsatları bence çok fazlaydı. Yüz yüze derslerde kimi zaman ruh halimiz dersi dinlemek istemeyebiliyordu. Not tutmak zorlaşıyordu. Dersin hızına yetişemeyebiliyordum. Ve de o ortam beni geriyordu. Ama evde ben o dersleri istediğim an izleyebiliyordum. Ev ortaminı verdiği güven ve rahatlkkla dinleyince dersler daha kahıı ve etkileyici oluyordu. Yüz yüze eğitimde alamadığım verimi aldım diyebilirim... Hatta bazen bazı dersleri iki defa dinliyordum. Böyle imkanları da vardı. Yani bu sürecin tamamen olumsuz olduğunu söylemek haksızhk olur...” (TÖA114)

\section{Dördüncü araştırma sorusuna yönelik bulgular}

SWOT analizinin son basamağı olan tehlikelere ilişkin bulgular Tablo 5’te verilmiştir. Türkçe öğretmeni adaylarının acil uzaktan öğretim programının neden olabileceği tehlikelere yönelik düşüncelerine bu bölümde değinilmiştir.

Tablo 5. Türkçe öğretmenliği acil uzaktan öğretim programının neden olabileceği tehlikelere yönelik bulgular

Sizce Covid-19 salgını sürecinde uygulanan lisans düzeyi Türkçe öğretmenliği acil uzaktan öğretim f programının neden olabileceği tehlikeler nelerdir?

\begin{tabular}{|c|c|c|}
\hline \multicolumn{2}{|l|}{ İletişim etkileşim ve sosyal öğrenme ortamının olmaması } & 32 \\
\hline \multicolumn{2}{|c|}{$\begin{array}{l}\text { Eğitim ihtiyaçlarına uygun uygulamalı bir öğrenme ortamı oluşturulamaması sonucu oluşan öğretmenlik } \\
\text { mesleği konusundaki yetersizlik gerçeği ya da kaygısı }\end{array}$} & 22 \\
\hline \multicolumn{2}{|c|}{ Ölçme ve değerlendirmede geçerlik, güvenirlik, adalet ve şeffaflığın sağlanamaması } & 19 \\
\hline \multicolumn{2}{|l|}{ Kalıcı ve tam öğrenmenin sağlanamaması } & 17 \\
\hline \multicolumn{2}{|l|}{ Okul ve çalışma disiplininden uzaklaşma } & 12 \\
\hline \multicolumn{2}{|c|}{ Devam zorunluluğu olmamasından kaynaklı rahatlık ve beraberinde gelen başarısızlık } & 11 \\
\hline \multicolumn{2}{|l|}{ Teknik aksaklıklar nedeniyle öğretimin kesintiye uğraması } & 10 \\
\hline \multicolumn{2}{|c|}{$\begin{array}{l}\text { Teknolojiye ulaşım ve ideal eğitim ortamına sahip olma konularında firsat eşitsizliğinin neden olduğu } \\
\text { öğrenme adaletsizliği }\end{array}$} & 8 \\
\hline \multicolumn{2}{|l|}{ Bireyselliğe ve yalnızlığa sürüklenme ve bağımlılık tehlikesi } & 8 \\
\hline \multicolumn{2}{|l|}{ Ö̆̆gretmen faktörünün etkisizleştirilmesi } & 4 \\
\hline \multicolumn{2}{|c|}{ Uzun süre bilgisayar kullanmanın neden olduğu sağlık sorunları } & 4 \\
\hline $\begin{array}{r}\text { Adres } \\
\text { RumeliDE Dil ve Edebiyat Araştrrmaları Dergisi } \\
\text { Osmanağa Mahallesi, Mürver Ciçeği Sokak, No:14/8 } \\
\text { Kadıköy - İSTANBUL / TÜRKIYE } 34714 \\
\text { e-posta: editor@rumelide.com } \\
\text { tel: +90 505 7958124, +90 216 } 773 \text { o } 616\end{array}$ & $\begin{array}{l}\text { Address } \\
\text { RumeliDE Journal of Language and Literature Studies } \\
\text { Osmanağa Mahallesi, Mürver Çiceği Sokak, No:14/8 } \\
\text { Kadıköy - ISTANBUL / TURKEY 34714 } \\
\text { e-mail: editor@ rumelide.com, } \\
\text { phone: +90 505 7958124, +90 } 216773 \text { o } 616\end{array}$ & \\
\hline
\end{tabular}




\begin{tabular}{lc}
\hline Gerçek dünyadan uzaklaşma sanal dünyaya kapılma & 4 \\
\hline Teknoloji kullanma bilgisi olmayanın doğrudan başarısız olması & 3 \\
\hline
\end{tabular}

Türkçe öğretmeni adayları acil uzaktan öğretim programından kaynaklı tehlike olarak en çok iletişim, etkileşim ve sosyal öğrenme ortamının olmamasını görmektedirler. Yine uygulama eksikliğinden kaynaklı mesleki yetersizlik kaygısı ve ölçme değerlendirmedeki sorunlar uzaktan öğretim programıyla ilgili en sık dile getirilen diğer tehlikeler olarak sıralanmaktadır. Teknoloji kullanma bilgisi olmayanın doğrudan başarısız olması konusu ise sıklığı en düşük tehlike olarak yer almaktadır.

Acil uzaktan öğretim programının tehlikelerine ilişkin bazı Türkçe öğretmeni adaylarının yazılı görüşleri aşağıda verilmiştir.

"Zayıf iletişim, sosyalleşmekten uzak bireyler, okumayan, yazmayan, her türlü öğrenci aktivitesinin yer aldığı derslerden uzak kalınması öğrencilerde gelecekte olumsuz yönler oluşmasına neden olacaktır." (TÖA13)

"Sinavlarda veya ödevlerde birçok öğrenci yardımlaşarak derslerini geçti. Bu sebeple vasıfsı bir öğretmen olma tehlikelisi doğdu. Üniversiteyi kopya ile geçen öğrenci ilerde öğrencisinden kopya çekmemesini isteyecek." (TÖA18)

"Bireylerin eğitimden soğumalarma sebebiyet verdiğini düşünüyorum. Her ne kadar eğitim devam etmiş olsa da uzaktan olmuş olması bence eğitimin ikinci plana atılmasina sebep oldu. İnsanlar hayatlarıyla, hastalıklarla mücadele ederken eğitim pek ön planda kalamadı maalesef." (TÖA68)

"Uzun bir süre uzaktan eğitim süreci bizim asosyal olmamıza sebep oldu ve eğitim öğretim bilginin yeri olduğu kadar sosyalliğ in ve iletişimin de yeri. Bu süreçte izole olmuşluk duygusu çok fazlaydı. Eski normalimize döndüğümüzde bu değişime yeniden ayak uydurmak, yeniden eski ders düzeni ve eski sınav düzenine ayak uydurma konusunda kendi adıma endişelerim var. Sanki her şey çok zor olacakmış gibi ve normal olana alışamayacakmışım gibi.” (TÖA93)

\section{Tartışma sonuç ve öneriler}

Bu çalışmada Covid-19 sürecinde uygulanan Türkçe öğretmenliği lisans düzeyi acil uzaktan öğretim programının Türkçe öğretmeni adaylarının görüşlerinden hareketle SWOT analizi yapılmıştır. Çalışmanın bulgularından hareketle ulaşılan sonuçlar bu bölümde alan yazından ilgili araştırmalardan hareketle tartışmalı bir şekilde verilecektir. Alan yazında bu konuda aynı şartlarda yapılan bir çalışmaya araştırmacı tarafından ulaşılamadığından aynı konuda yapılan diğer çalışmaların sonuçlarından hareketle bir tartışma gerçekleştirilecektir. Bölümün sonunda çalışmada elde edilen bulgular ve ulaşılan sonuçlardan hareketle birtakım önerilere yer verilecektir. Türkçe öğretmenliği acil uzaktan öğretim programına yönelik gerçekleştirilen SWOT analizinde Türkçe öğretmeni adaylarının her bir kategori ile ilgili verdikleri en sık ilk üç cevap Şekil 1'deki SWOT matrisinde gösterilmiştir. SWOT matrisi güçlü ve zayıf yönlerin, firsatların ve tehditlerin bütüncül bir şekilde verildiği ve buradan hareketle çeşitli kombinasyonların oluşturulabileceği bir yapıdır. Araştırmayla ilgili ulaşılan sonuçlar sıralanırken bu matristen de yararlanılacaktır.

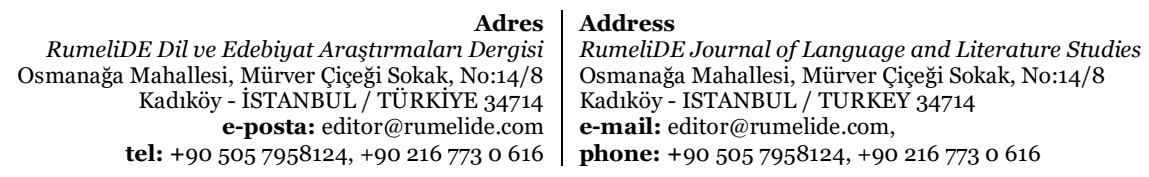




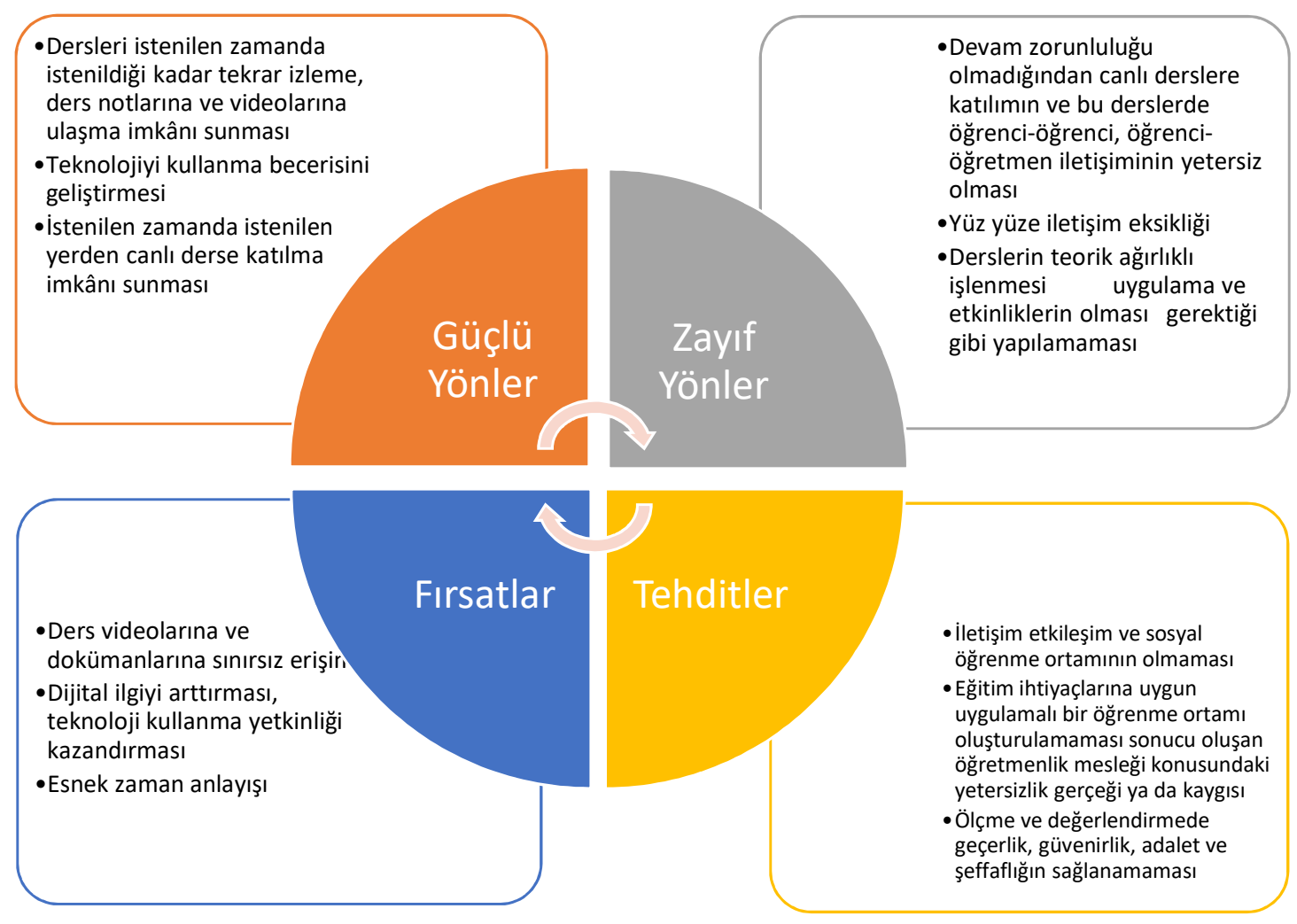

Şekil 1. SWOT matrisi

Elde edilen bulgulardan hareketle Türkçe öğretmeni adaylarının görüşleri kapsamında acil uzaktan öğretim programının güçlü yönlerinin zaman, yer ve katılım konusunda esneklik, teknoloji kullanma yeterliliğini arttırma ve istenildiği zaman derse, dersle ilgili dokümanlara ulaşılabilmesi olduğu sonucuna ulaşılmıştır. Türkçe öğretmeni adaylarının acil uzaktan öğretim programının güçlü yanlarıyla ilgili olarak içeriksel tespitler yapmaması daha çok genel yapı ile ilgili görüşler belirtmesi dikkat çekicidir. Ayrıca araştırmaya katılan 118 Türkçe öğretmeni adayından 2'si güçlü yönler arasında acil uzaktan Türkçe öğretim programının dinleme becerisini geliştirdiğine vurgu yapmışlardır. Karakuş, Ucuzsatar, Karacaoğlu, Esendemir ve Bayraktar (2020) tarafından yapılan Türkçe öğretmeni adaylarının uzaktan eğitime ilişkin görüşlerinin incelendiği çalışmada da 54 Türkçe öğretmeni adayından 8’i benzer bir tespitte bulunmuştur. Yine aynı çalışmada 51 Türkçe öğretmeni adayının \%55,4 uzaktan eğitimin okuma becerisine etkisinin düşük olduğunu belirtirken bu çalışmada da 118 Türkçe öğretmeni adayından 2'si acil uzaktan Türkçe öğretim programının okuma becerisini geliştirdiğini belirtmiştir. Özüdoğru (2021) ise Uşak Üniversitesinde eğitim alan farklı branşlardan 24 öğretmen adayı ile gerçekleştirdiği çalışmasında bu çalışmadaki sonuçlarla örtüşecek biçimde acil uzaktan öğretimin öğretmen adaylarının hazır bulunuşluğunu güçlendirdiği ve kendi öğrenme sorumluluklarını almalarını sağladığı sonuçlarına ulaşmıştır. Uysal-Bayrak, Tanık-Önal (2021) ise okul öncesi öğretmen adaylarının uzaktan eğitimle işledikleri Topluma Hizmet Uygulamaları dersine ilişkin gerçekleştirdikleri SWOT analizi şeklindeki çalışmalarında okul öncesi öğretmeni adaylarının bu ders kapsamında güçlü yönler olarak uzaktan eğitimi ekonomik buldukları, uzaktan eğitimin internette araştırma yapma becerisi imkanını geliştirdiği, kendi kendine öğrenmeye yönlendirdiği, iletişim ve etkileşimi geliştirdiği gibi bu çalışmadaki sonuçlarla örtüşen sonuçlara ulaşmışlardır. Söz konusu çalışmada uzaktan eğitimin güçlü yönleriyle ilgili olarak okul öncesi öğretmeni adayları tarafından grupla çalışma becerisi kazandırma,

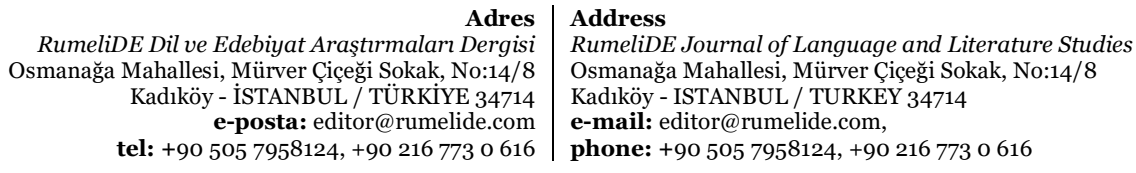


eğlenceli olma ve kurumlardan izin alma prosedürleriyle uğraştırmama gibi farklı tespitler de yapılmıştır. Bu verilerden hareketle farklı branşlardan öğretmen adaylarının acil uzaktan öğretimin güçlü yönleriyle ilgili görüşlerinin alındığı çalışmalarda benzer sonuçlara ulaşıldığı görülmüştür.

Covid-19 salgını sürecinde uygulanan Türkçe öğretmenliği acil uzaktan öğretim programının Türkçe öğretmeni adayları tarafından belirtilen zayıf yönlerinin yüz yüze etkileşim eksikliği, sınıf disiplininin sağlanamaması, teknolojik donanım eksikliği nedeniyle derslerin takip edilememesi, ölçme ve değerlendirmede adaletin sağlanamaması, uygulama derslerinin yapılamaması olduğu sonucuna ulaşılmıştır. Özüdoğru (2021) ise uzun canlı oturumlar, aşırı ödev yüklemesi, etkileşim ve uygulama eksikliği, güvenilir olmayan çevrimiçi sınavlar şeklinde sıralanan ve yine bu çalışma ile örtüşen sonuçlara ulaşmıştır. Uysal-Bayrak, Tanık-Önal (2021) okul öncesi öğretmeni adaylarının görüşlerinden hareketle uzaktan eğitim sürecinin zayıf yönleriyle ilgili uygulamalı derslerin yapılamaması, iletişim ve etkileşim eksikliği, yeterli donanıma sahip olmamak ve mesleki deneyim kazanamamak sonuçlarına ulaşmıştır. Karakuş, Ucuzsatar, Karacaoğlu, Esendemir ve Bayraktar (2020)'ın çalışmasında ise Türkçe öğretmeni adaylarının \%77,2'si uzaktan eğitim sürecinde görev ve sorumluluklarının arttığını düşünmektedir. Uzaktan öğretim programının zayıf yönlerine ilişkin farklı branşlarda öğretmen adaylarıyla, farklı zamanlarda ve farklı şekillerde yapılan çalışmalarda benzer sonuçlara ulaşıldığı görülmüştür. Başta Türkçe ve okul öncesi öğretmeni adayları olmak üzere bütün branşlarda zayıf yönlere ilişkin ortak tespitlerin olması dikkat çekicidir.

Acil uzaktan öğretim programının sunduğu firsatlara ilişkin Türkçe öğretmeni adaylarından elde edilen bulgular incelendiğinde programın ders dokümanlarına sınırsız erişim, dijital ilgiyi arttırma ve teknoloji kullanım yetkinliği sağlama, zaman ve öğrenme ortamı konusunda esneklik, diğer yaşam aktivitelerine olanak sağlama, araştırma merakı, bireysel öğrenmeyi destekleme, eğitimde sürekliliği sağlama gibi firsatlar sunduğu sonucuna ulaşılmıştır. Uysal-Bayrak, Tanık-Önal (2021) uzaktan eğitimin sunduğu fırsatlar olarak kişisel gelişim sağlamak, öğrenme zamanı ile ilgili esneklik, dijital yetkinlik, mesleğe karşı olumlu tavır geliştirme şeklinde bir sıralama yapmışlardır. Özüdoğru (2021) ise uzaktan öğretimin öğrenmeye hazırlık sürecini geliştirdiği ve problem çözme becerisini arttırdığı gibi kişisel fırsatlar olarak değerlendirilen sonuçlara ulaşmıştır. Araştırmanın firsatlar anlamında diğer iki çalışmadan daha geniş çerçeveye sahip olduğu diğer iki çalışmada fırsatlarla ilgili sınırlı veriye ulaşıldığı görülmüştür. Ayrıca konuyla ilgili Türkçe öğretmeni adaylarıyla yapılan Karakuş, Ucuzsatar, Karacaoğlu, Esendemir ve Bayraktar (2020)'ın çalışmasında ise araştırmanın amacı ve araştırma soruları farklı olduğundan firsatlar ile ilgili veriye rastlanılmamıştır.

Son olarak acil uzaktan Türkçe öğretim programının neden olabileceği tehditlere ilişkin Türkçe öğretmeni adaylarının cevapları incelendiğinde programın iletişim, etkileşim ve sosyal ortamın olmaması, uygulamalı derslerin yapılamasından kaynaklı mesleki yetersizlik kaygısı, ölçme ve değerlendirmede adaletin ve şeffaflığın sağlanamaması, kalıcı ve tam öğrenmenin sağlanamaması, okul kavramından ve çalışma disiplininden uzaklaşma, teknolojiye ulaşım imkanı olmayanların öğrenmede dezavantajlı duruma gelmesi, bireyselliğe ve yalnızlığa sürüklenme, teknoloji bağımlılığı, öğretmen unsurunun önemsizleştirilmesi, uzun süreli bilgisayar ve cep telefonu kullanımından kaynaklı sağllk sorunları gibi tehlikelere neden olabileceği sonucuna ulaşılmıştır. Uysal-Bayrak, Tanık-Önal (2021) ise uzaktan Topluma Hizmet Uygulamaları dersine yönelik öğretmen adayları tarafından belirtilen teknolojik alt yapı eksikliğinden kaynaklı sorunlar, denetim zorluğu ve ders içeriğinden kaynaklı sorunlar şeklinde tehditlerin olduğu sonucuna ulaşmışlardır. Bu anlamda araştırmanın daha kapsamlı olduğunu ve çalışmada tehditlere ilişkin detaylı sonuçlara ulaşıldığını söylemek mümkündür.

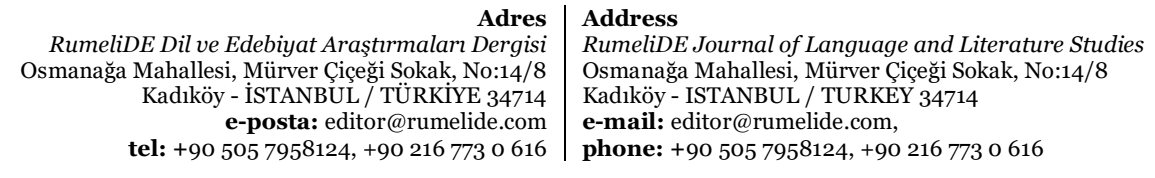


$\mathrm{Bu}$ konuda çalışma yapacak araştırmacılara öğretmen, öğrenci, yönetici ve veli şeklinde bütün paydaşların dikkate alındığı daha geniş örneklem ve gruplarla çalışma yapmaları önerilebilir. Uzaktan öğretim yaklaşımıyla ders işleyen öğretmenlere teknolojik yetkinlik konusunda kendilerini geliştirmeleri ve sürece uygun ilgi çekici yöntem ve materyaller kullanmaları tavsiye edilebilir. Ayrıca öğretmenlerin öğretmen-öğrenci, öğrenci-öğrenci etkileşim ve iletişimine önem vermeleri yararlı olabilir. Program hazırlayıcıların öğrenci ihtiyaçlarını ve imkanlarını gözeterek hareket etmeleri ölçme ve değerlendirmede geçerlik, güvenirlik ve şeffaflığı să̆lamaları, öğrencilere her aşamada alternatifler sunmaları ve bunu belirli bir disiplin içerisinde gerçekleştirmeleri acil uzaktan öğretim sürecinin başarısını arttırmada yararlı olabilir. Konuyla ilgili üzerinde anlaşma sağlanmış kavram ve anahtar sözcüklerin kullanılması kavram karmaşasını önleme anlamında yararlı olabilir.

\section{Kaynakça}

Aköz, Ö. (2019). Millî Eğitim Bakanlığına bağlı yurt dışı okulların SWOT analizi. Yayınlanmamış Yüksek Lisans Tezi. Hacettepe Üniversitesi Sosyal Bilimler Enstitüsü.

Birel, F. K. (2008). Çankaya ve Bismil ilçe milli eğitim müdürlüklerinin güç çözümlemesi (SWOT analizi). Yayınlanmamış Doktora Tezi. Hacettepe Üniversitesi Sosyal Bilimler Enstitüsü.

Bozkurt, A., \& Sharma, R. C. (2020). Emergency remote teaching in a time of global crisis due to CoronaVirus pandemic. Asian Journal of Distance Education, 15(1), i-vi. https://doi.org/10.5281/zenodo.3778083.

Bozok, Ö. (2019). Teknik bilimler meslek yüksek okullarında İngilizce dersine yönelik SWOT analizi. Yayınlanmamış Yüksek Lisans Tezi. Hacettepe Üniversitesi Eğitim Bilimleri Enstitüsü.

Carmen Carrillo \& Maria Assunção Flores (2020) COVID-19 and teacher education: a literature review of online teaching and learning practices, European Journal of Teacher Education, 43:4, 466-487, DOI: $10.1080 / 02619768.2020 .1821184$.

Creswell, J. W. (2017). Araştırma Deseni. (Çev. Murat Bursal- Çev. Ed. Selçuk Beşir Demir). Ankara: Eğiten Kitap.

Çekmez, E., Yıldız, C., \& Bütüner, S. Ö. (2012). Fenomenografik araştırma yöntemi. Necatibey Eğitim Fakültesi Elektronik Fen ve Matematik Eğitimi Dergisi, 6(2), 77-102.

Duban, N., Şen, F. G. (2020). Sınıf öğretmeni adaylarının COVID-19 pandemi sürecine ilişkin görüşleri. Turkish Studies, 15(4), 357-376. https://dx.doi.org/10.7827/TurkishStudies.43653.

Er-Türküresin, H. (2020). Covid-19 pandemi döneminde yürütülen uzaktan eğitim uygulamalarının öğretmen adaylarının görüşleri bağlamında incelenmesi. Milli Eğitim Dergisi, 49 (1), 597-618. DOI: $10.37669 /$ milliegitim.787509.

Gelişli, Y. (2015). Uzaktan Eğitimde Öğretmen Yetiştirme Uygulamaları: Tarihçe ve Gelişim, Journal of Research in Education and Teaching, 4(3). 313-321.

Gökbulut, B. (2021). Uzaktan eğitim öğrencilerinin bakış açısıyla uzaktan eğitim ve mobil öğrenme. Eğitim Teknolojisi Kuram ve Uygulama, 11(1), 160-177.

Gök-Çolak, F., \& Efeoğlu, G. (2021). Yeni normalleşme sürecinde öğretmenlik uygulaması dersine yönelik ihtiyaç analizi Swot analizi örneği. Kesit Akademi Dergisi, 7(27), 176-197.

Gökmenoğlu T., ve Eret E. (2011). Eğitim programları ve öğretim ana bilim dalı araştırma görevlilerinin bakış açısıyla Türkiye'de program geliştirme. Elemantary Education Online.

Johannes König, Daniela J. Jäger-Biela \& Nina Glutsch (2020) Adapting to online teaching during COVID-19 school closure: teacher education and teacher competence effects among early career teachers in Germany, European Journal of Teacher Education, 43:4, 608-622, DOI: 10.1080/02619768.2020.1809650.

Kaçan, A., \& Gelen, İ. (2020). Türkiyedeki uzaktan eğitim programlarına bir bakış. Uluslararası Eğitim Bilim ve Teknoloji Dergisi, 6(1), 1-21.

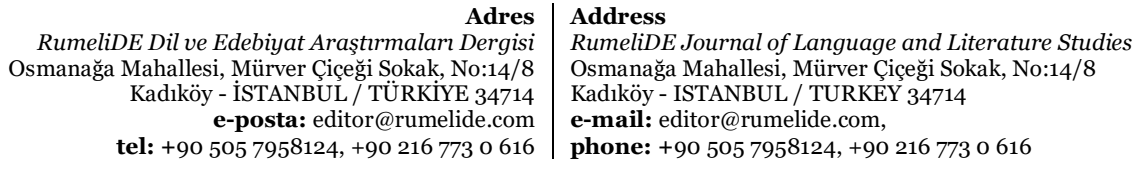


Karakuş, N.; Ucuzsatar, N.; Karacaoğlu, M. Ö.; Esendemir, N.; Bayraktar, D. (2020). Türkçe öğretmeni adaylarının uzaktan eğitime yönelik görüssleri. RumeliDE Dil ve Edebiyat Araştırmaları Dergisi, (19), 220-241. DOI: 10.29000/rumelide.752297.

Kaya, Z. (2002). Uzaktan Eğitim. Ankara: Pegem A.

Kırı, A. M. (2014). Uzaktan eğitimin tarihsel gelişimi ve Türkiye'deki durumu. Marmara İletişim Dergisi, 21, 73-94.

Linda la Velle, Stephen Newman, Catherine Montgomery \& David Hyatt (2020) Initial teacher education in England and the Covid-19 pandemic: challenges and opportunities, Journal of Education for Teaching, 46:4, 596-608, DOI: 10.1080/02607476.2020.1803051.

Linor L. Hadar, Oren Ergas, Bracha Alpert \& Tamar Ariav (2020) Rethinking teacher education in a VUCA world: student teachers' social-emotional competencies during the Covid-19 crisis, European Journal of Teacher Education, 43:4, 573-586, DOI: 10.1080/02619768.2020.1807513.

Maria Assunção Flores \& Marīia Gago (2020) Teacher education in times of COVID-19 pandemic in Portugal: national, institutional and pedagogical responses, Journal of Education for Teaching, 46:4, 507-516, DOI: 10.1080/02607476.2020.1799709.

Merriam, S. B. (2015). Nitel Araştırma. (Çev. Selahattin Turan). Ankara: Nobel Akademik.

Orr, B. (2013). Conducting a SWOT analysis for program improvement. US-China Education Review, $3(6), 381-384$.

Özarslan, Y., \& Ozan, Ö. (2014). Yükseköğretimde Uzaktan Eğitim Programı Açma Sorunsalı, XIX. Türkiye'de İnternet Konferansı, Yaşar Üniversitesi, İzmir.

Özüdoğru, F. (2021). Turkish preservice teachers experiences with emergency remote teaching a phenomenological study. Issues in Educational Research, 31 (1), 166-187.

Penchev, D. (2021). SWOT analysis as a research method in pedagogy. Pedagogy, 93(5), 669-678.

Saltürk, A., \& Güngör, C. (2020). Üniversite öğrencilerinin gözünden Covid-19 pandemi döneminde uzaktan eğitime geçiş deneyimi. Adıyaman Üniversitesi Sosyal Bilimler Enstitüsü Dergisi, 36, 137174.

Shirley Van Nuland, David Mandzuk, Krista Tucker Petrick \& Terri Cooper (2020) COVID-19 and its effects on teacher education in Ontario: a complex adaptive systems perspective, Journal of Education for Teaching, 46:4, 442-451, DOI: 10.1080/02607476.2020.1803050.

Telli, S. G. \& Altun, D. (2020). Coronavirüs ve çevrimiçi (online) eğitimin önlenemeyen yükselişi. Üniversite Araştırmaları Dergisi, 3 (1), 25-34. DOI: 10.32329/uad.711110.

Ustabulut, M. Y. (2021). SWOT analysis for the distance education process of lecturers teaching Turkish as a foreign language. Educational Policy Analysis and Strategic Research, 16(1), 139-152.

Uysal-Bayrak, H., \& Tanık-Önal, N. (2021). SWOT analysis of distance education based on preschool teacher candidates. International Journal of Eurasian Education and culture, 6(12), 189-234.

Viv Ellis, Sarah Steadman \& Qiming Mao (2020) 'Come to a screeching halt': Can change in teacher education during the COVID-19 pandemic be seen as innovation?, European Journal of Teacher Education, 43:4, 559-572, DOI: 10.1080/02619768.2020.1821186.

Warren Kidd \& Jean Murray (2020) The Covid-19 pandemic and its effects on teacher education in England: how teacher educators moved practicum learning online, European Journal of Teacher Education, 43:4, 542-558, DOI: 10.1080/02619768.2020.1820480.

Yıldırım, A. ve Şimşek, H. (2011). Sosyal bilimlerde nitel araştırma yöntemleri (8. Baskı). Ankara: Seçkin.

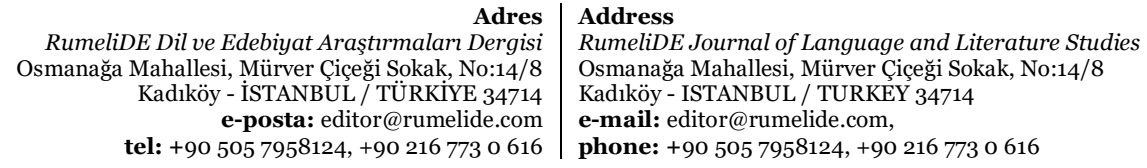

e-posta: editor@rumelide.com

phone: +90 505 7958124, +90 2167730616 